\title{
Accounting for innovations in value management of companies in the context of globalization
}

\author{
Svitlana Semenova ${ }^{1, *}$, Olena Fomina ${ }^{1}$, and Olena Moshkovska ${ }^{1}$ \\ ${ }^{1}$ Kyiv National University of Trade and Economics, Department of Accounting and Taxation, Kyiv, \\ 19, Kyoto str., Ukraine
}

\begin{abstract}
.
Research background. Given that innovations have a great impact on gaining competitive advantage and long-term growth of the company's value, it is important to find ways to fully and correctly reflect them in the accounting and reporting system to provide users with the necessary information to make effective decisions.

Purpose of the article is to characterize the accounting of innovations in the value management system of the enterprise and determine the form of integrated reporting on innovations to assess their impact on the value of the company and make effective decisions.

Methods. The methodological basis of the study consists of informal content analysis of information, systematic approach, deductive method, comparison, abstraction, grouping and systematic generalization.

Findings \& Value added. The disadvantage of the current accounting system is the attribution of investment in intangible innovations to the company's costs, which is not considered and is not reflected as a longterm competitive advantage. Thus, not taking into account the intangible non-accounting factors of generating the value of the company, which are associated with innovation, intellectual capital, can significantly underestimate the book value of the company compared to its market value. The value of the company stated in the financial statements may be significantly lower than its market value due to the failure to take into account in the system of accounting for the interaction of innovation with intellectual, environmental and social capital, which is the source of domestic goodwill. Innovation accounting requires the allocation of appropriate facilities and the formation of integrated reporting to provide comprehensive information for decision-making in the management of the company's value.
\end{abstract}

Keywords: accounting; innovations; value management; reporting

JEL Classification: $M 41 ; O 31 ; M 10$

\footnotetext{
*Corresponding author: s.semenova@knute.edu.ua
} 


\section{Introduction}

Problems of valuation and management of companies in modern business conditions are increasingly attracting the attention of managers, scientists and researchers. One of the important tasks of business management is to increase its value, ensure the well-being of owners, so the goal of increasing the value of companies is of particular importance. Innovations are able to provide higher indicators of competitiveness, profitability and, consequently, the value of the business. Therefore, such an important object of accounting as innovation must be considered in the context of company value management.

The most innovative economies in the world are Germany (86.8), the United States (84.1), Switzerland (81.2) and Taiwan (China) (80.2) [1], in parentheses is the indicator of innovation capacity from 0 to 100 according to the World Economic Forum for 2019. These countries also have the highest GCI 4.0 (Global Competitiveness Index) indicators. The country's innovation capacity is calculated using a number of indicators, including: diversity of workforce, state of cluster development, multi-stakeholder collaboration, research and development, scientific publications score, research institutions prominence, commercialization, international co-inventions, patent applications and trademark applications per million pop. In these four countries, innovation scores exceed 80 in terms of innovation capacity. Only 141 out of 141 countries of the world have the value of innovation capacity more than 50 , the average in the world is only 38 . The Global Competitiveness Index [1] identifies and evaluates the factors underlying the process of economic growth and human development, where innovation has a special role. Therefore, innovation must be evaluated, analyzed and reflected in accounting and reporting as one of the key factors in the long-term growth of the company's value.

The process of assessing the value of the enterprise is primarily carried out in the accounting system, but often the book value of the company does not correspond to its market value, which explains the nature of goodwill. The existence of a large number of methods of valuation of the enterprise is associated with different interests of the subjects of evaluation: accountants, managers, owners, auditors, creditors, investors, banks, insurers, who use different tools and indicators. The whole set of methods for calculating the value of the company can be systematized into three approaches [2]: cost, revenue and market, each of which has its own characteristics, disadvantages and advantages. The greatest impact of innovation on increasing the value of companies is taken into account in the revenue approach to valuation, but it requires accurate forecast estimates, the stability of the environment and relies heavily on the application of professional judgment of the accountant.

The financial statements generated by the accounting system contain a retrospective assessment of the results of transactions and do not provide complete information about the current real value of the company, its potential to generate future cash flows, competitive position in the market, ambitions and ability to innovate, the expected effect. Innovation is a complex object of accounting it goes beyond the traditional understanding of assets and costs. This requires a special approach to the reflection of innovations in accounting and reporting to provide complete information to users about their impact on the value of the company to make effective decisions.

Research objective. The purpose of the article is to highlight the features of accounting for innovations in company value management and reporting to meet the information needs of users in decision-making.

Methodology and data. The methodological basis of the study is informal content analysis and systematic generalization of data obtained from scientific and practical sources of information on accounting for innovation and value formation of companies. The 
performed investigations are based on the application of a systematic approach, deductive method, comparison, abstraction, grouping and generalization methods.

Structurally, the article contains a statement of the problem, a review of the scientific literature, determining the purpose of the study, methods of obtaining results. The article describes the importance and need to take into account in the accounting and reporting system the impact of innovations on the value formation of companies in today's globalization. The essence of concepts is investigated: innovation, innovative activity, expenses for innovation, internal goodwill. The main features of the classification of innovations as an object of accounting are identified. Problems and obstacles to the full display of information about the company's innovations, namely their impact on the growth of the company's value are outlined. It is necessary to take into account off-balance book value indicators, off-accounting factors associated with the positive effect of innovation on the growth of the value of companies. For this purpose, a form of integrated reporting on innovations in company value management is proposed. The main indicators of this form include information about innovation as a process (as part of innovatiove activity), innovation as a result (innovative product and innovative production) and expected results from innovations. The form of integrated reporting should contain indicators of the value of the enterprise, which are reflected in the balance book, and cost factors outside the financial accounting system, off-balance book value indicators of the enterprise, which are taken into account in management internal reporting. Thus, it will control and obtain information not only about the results of innovative activities of the enterprise, reflected in the accounting system according to the current methodology, but also those parameters that directly or potentially affect the value of the company, but not yet reflected in the financial statements. More complete information support will help to make effective management decisions about innovations and their impact on the company's value.

\section{Literature review}

Innovation is a widely studied object, but the issues of accounting for innovation in relation to the value of the enterprise in the scientific literature are not sufficiently disclosed.

The real impact of financial reporting on the disclosure of information about the company's innovation is highlighted by Simpson A. and Tamayo A. [3] and points to the difficulties in reporting on investment in innovation. Given the set of characteristics of the company's innovation activities, the disclosure of information about innovations can be carried out in three sections: financing, compensation and training. The reflection of innovations in accounting and financial reporting requires a compromise between reducing the asymmetry of the information presented and increasing own costs. The appropriate approach is also followed by Cooper S. [4], pointing to the need to find special detailed forms of disclosure of information about innovations and developments in the financial and management reporting of companies.

The source of information about the innovative activity of the enterprise is financial, managerial, statistical accounting and reporting. However, today the method of reflection in the accounting of innovation processes is imperfect, as it relies on existing tools that do not take into account off-balance sheet and intangible factors of innovation, such as intellectual capital, synergy, competitiveness, the impact of integration and globalization [5].

The impact of business innovation on human development in the country was studied by Sajjad M., Orangzab, Chani M.I. [6]. The global business index, business innovation indicators and the development of intermediate indicators of human potential: behavior, abilities and level of aspiration were analyzed. In particular, it was found that the level of desire of employees is influenced by existing industrial innovations, innovative production methods, the level of internationalization and the amount of venture capital. The human 
development index is growing due to the intensification and spread of innovations in the field of entrepreneurship, which in turn due to the increase in intellectual capital contributes to the value of companies.

The consequences of changes in accounting approaches to reflect the processes of mergers and acquisitions, assessment of goodwill generation, acquisition of research projects and developments are studied in detail by Chaney P. K., Gunn R. N. and Jeter C. D. [7]. It is pointed out that due to changes in international financial reporting standards, the GAAP system, there is a great deal of debate as to whether the proposed accounting changes may provide distorted information and prevent optimal decision-making. The use of combinations of business and innovation by international companies as a means of increasing their market value is becoming more difficult.

The need to take into account and calculate the intellectual capital in the composition of human capital, organizational capital and customer relations capital is emphasized by the authors Kutsyk P., Koryagin M., Chik M. and Kuskova S. [2]. It is reasonable to agree with the hypothesis that the value of intellectual capital can be determined only in the totality of its components, as each of them separately determines only the costs incurred of different nature. The same approach is relevant for assessing the importance of innovation in shaping and increasing the value of the company. The nature of the activity, the operating conditions of the enterprise and the complexity of innovations significantly affect the formation of the company's value.

Management accounting tools, including analytical and strategic, proposed by Mazaraki A. A. and Fomina O. V. [8] can be successfully used to more fully reflect the innovations in the management accounting system of the enterprise.

Modern challenges also require the introduction of innovations in the field of management accounting, the so-called MAIs (management accounting innovations), especially for international corporations, as noted by Yazdifar N., Askarany D., Wickramasinghe D., Nasseri A. and Alam A. [9]. Under the influence of globalization processes, management accounting and reporting become more socially oriented, attention is paid not only to innovations to strengthen the competitiveness of companies, but also to the components of intellectual and environmental capital as factors of value generation.

The literature also examines the impact of innovation on the quality of financial reporting. The presence of a two-way relationship between the volume (scale) of innovation and the quality of financial reporting indicates Park K. [10]. The formation of high-quality financial statements is based on a well-established system of information support of the company, where accounting plays a key role [11]. At the same time, high-quality accounting information and prepared financial statements can help the company in making decisions in the presence of a high degree of uncertainty about the expected benefits for innovation in intensive research and high competition in the market.

In their work, Dainiene R., Dagilienè L. [12] present an assessment of innovation in financial, managerial and social accounting. Problems of accounting for cost management are considered in the work of Kovova I., Malyshkin O., Vicen V., Shulyarenko S., Semenova S. and Shpyrko O. [13].

Innovations in the field of accounting are covered in the work of the authors Becker S.D., Messner M., Schäffer U. [14]. Historically sound and proven accounting innovations such as activity-based costing (ABC), economic value added (EVA), balanced scorecard (BSC), budgeting, management and integrated reporting emphasize the importance of management accounting and reporting in the management of company values. The development of the accounting system already goes beyond budgeting in the formation of strategic management accounting. All this emphasizes the urgency of finding new approaches and methods of accounting, reflecting not only the process of development 
and implementation of innovations, but also the impact on the growth of the company's value from the implementation of innovative activities.

\section{Results and Discussions}

Innovation is a new product in the field of engineering, technology, management, scientific and social activities, which is created based on the use of ideas and best practices. Innovation is inextricably linked to innovation, but it is an aggregate concept and a rather complex object of accounting.

On the one hand, innovation is an investment in research, development, testing, which are reflected in the accounting as the formation of costs or capital investment. Such innovations ensure the development of existing technologies [12]. On the other hand, innovations can be recognized as technologies as an asset, a new product or commodity, a new technique [14]. Such innovations are in fact the result of innovation.

Innovative activities are all scientific, organizational, financial, technological and commercial activities that promote the introduction of innovations or are designed for this purpose. Innovations are newly created, applied or improved competitive technologies, products or services, as well as organizational and technical solutions of production, administrative, commercial or other nature that significantly improve the structure and quality of production or social sphere. Innovation as an object of accounting should be divided into appropriate types, as they require different approaches to be reflected in accounting and affect the formation of company value in different ways [5, 15].

According to the Oslo Guidelines, in economic terms, innovations are divided into product, process, marketing and organizational. According to the market position, there are constant, intermittent and subversive innovations. According to the level of novelty, innovation is a new or significantly improved product, product or service. According to the level of innovation: new for the market or new for the company [5]. Fundamental from the point of view of accounting accounts and the order of reflection in the reporting is the classification of innovations by objects of innovations: commodity, technological, technical, managerial, marketing, ecological and social. Not all of these innovations may meet the strict criteria for recognizing an asset, but because they have potential economic benefits, they should be considered as part of the company's off-balance sheet value factors.

Innovative activity is aimed at using the results of research and development, their commercialization, leads to the release of new competitive goods and services on the market $[9,16]$.

Research and development are divided into internal, created by the enterprise itself, where the amount of capital investment, cost of innovative objects will be recognized; and external - purchased from other companies.

There are also such types of innovative activities as the purchase of machinery, equipment, software and other external knowledge. Innovative activities include education and training of personnel, which have a significant investment character, as they are able to increase the intellectual capital of the enterprise and increase its value in the long run.

A separate component of innovation is the market introduction of innovations, their presentation on the market or direct use in production.

Depending on the stage of implementation, it is appropriate to distinguish as separate objects of accounting: the cost of innovation and innovation as a result. The cost of innovation is a set of invested resources, the cost of the still unfinished process of creating innovations that have not yet reached the planned goal [7]. Innovation as a result, in turn, can be divided into innovative product and innovative products [10]. An innovative product is the result of research and development, which meets the established requirements [16]. Innovative products are certain new products or services. 
Among the forms of acquisition of new technologies are: patent rights, licenses for the use of inventions, industrial designs, utility models; results of research and development; know-how, agreements for the acquisition or transfer of technology; purchase of equipment; purposeful involvement of qualified specialists.

Innovations are closely related to the functioning of intellectual capital in the enterprise, the generation of internal goodwill, the existence of off-balance sheet factors that can't be fully reflected in the existing method, but contribute to the market value of the enterprise, so require consideration, evaluation and reflection and management accounting. The definition of the methodology for evaluating innovations by stages of implementation and identification of the transition of intellectual capital to innovation remains relevant today [5].

Based on the fact that innovative products are objects of intellectual property, a prerequisite for their recognition is accounting, official registration of such a product by the developer or author of ownership of the results of innovation at the state level [2, 4]. Such documents include patents for inventions, certificates, licenses, which assign to the subjects of innovation copyright and related rights. In this way, intellectual property is recognized, which is reflected in the account as an intangible asset of the enterprise.

Problems of accounting for innovations are the lack of separate accounts for their reflection in the accounting system. In practice, analytical sub-accounts are used to reflect the costs, operations and results associated with innovation $[6,11]$. In turn, this requires the development of appropriate forms of internal management reporting that would meet the information needs of users in decision-making.

In the account for each object of intellectual property are: invention, utility model, industrial design, topography of the integrated circuit, selection achievement, analytical sub-account is opened. The company as a producer of innovation has state protection documents - patents and certificates. Upon receipt of intellectual property from their owners, a license for their use, sale or implementation of the discovery is required.

In the financial accounting system, an asset that is the result of an innovation is recognized primarily as an intangible asset. If, as a result of an innovation activity, it is not possible to recognize an intangible asset, the costs of innovation, the costs of the period, are recorded.

The total cost of innovation is the cost of the enterprise to innovate both new to the enterprise and new to the market, including internal research and development, acquisition of developments, machines, equipment and software, other external knowledge and other costs. The indicator includes current and capital expenditures. Data on the cost of innovation are provided regardless of the stage of the innovation process: at the initial stage of development of new or significantly improved products and processes or at an intermediate stage.

Thus, as an object of accounting, innovations are closely related to innovation, income and expenses, intellectual capital, intangible assets, which are reflected in the balance sheet or which are defined as off-balance sheet resources. IAS 38 [15] also applies to measures aimed at increasing intellectual capital, spending on advertising, training, commissioning, development and research aimed at developing knowledge.

Businesses often recognize the costs of innovation in the acquisition, development, maintenance or enhancement of intangible resources, such as technical or scientific knowledge, development and implementation of new technologies and systems, licenses, intellectual property, market research and trademarks [13]. Not all objects of innovation meet the definition of an intangible asset due to the impossibility of identification or control over the resource, difficulties in proving the existence of future economic benefits, reliable valuation. If the component of intellectual capital related to innovation does not meet the criteria for recognition of an intangible asset, the cost of its acquisition or internal 
generation is recognized as an expense in the period. However, if the item was acquired in a business combination, it is part of the goodwill recognized at the acquisition date [1].

Internally generated goodwill is not recognized as an asset. If an enterprise innovates but does not create an intangible asset, such costs are characterized as a contribution to internally generated goodwill. Internally generated goodwill is not recognized as an asset because it is not an identifiable resource (that is, it is not separable and does not derive from contractual or other legal rights) that is controlled by the entity and that can be measured reliably at cost $[3,8]$. Internally generated goodwill is an important part of a company's value management.

The value of the company presented in the statement - the statement of financial position, is based on accounting estimates, rules of recognition of assets, the capital and obligations. However, the current accounting system according to international standards is not yet able to fully assess and reflect all components of intangible assets that significantly affect the formation of the market value of the company. Such components of intellectual capital as: human capital (knowledge, skills, creativity, creativity of employees, their values), organizational capital (organizational structure, information logistics, corporate culture of the company), customer or consumer capital (customer relations). Part of the intellectual capital may be reflected in the intangible assets of the company: patents, licenses, know-how, trademarks and intellectual property rights. However, most components cannot be recognized as assets due to the complexity of valuation or lack of control, ownership by the enterprise. In addition, such components of intellectual capital have the potential to bring the company future economic benefits, increase its market value. Therefore, they must be identified and reflected in internal management reporting in order to control, influence and make effective decisions. In addition to intellectual capital, offbalance sheet factors also include environmental capital, internal systemic synergy effects from the use of resources, the positive manifestation of which is significantly influenced by innovation. Therefore, for accounting and effective innovation management it is important to build integrated management reporting, which would provide sufficient and reliable information about the impact of innovation on the formation of company value (Table 1).

Table 1. Form of integrated reporting on innovations in company value management

\begin{tabular}{|c|c|c|c|}
\hline \multicolumn{2}{|c|}{ Indexes } & $\begin{array}{l}\text { The cost of the enterprise } \\
\text { in the system of financial } \\
\text { accounting (book value) }\end{array}$ & $\begin{array}{l}\text { Factors of enterprise value outside } \\
\text { the financial accounting system } \\
\text { (off-balance book value indicators) }\end{array}$ \\
\hline \multirow{3}{*}{$\begin{array}{l}\text { Innovation } \\
\text { as a process }\end{array}$} & \multirow{3}{*}{$\begin{array}{l}\text { Innovative } \\
\text { activity }\end{array}$} & Capital Investments & Ecological capital, intellectual capital \\
\hline & & Period costs & Organizational capital \\
\hline & & $\begin{array}{l}\text { Staff training and education } \\
\text { costs }\end{array}$ & $\begin{array}{l}\text { Human capital, employee } \\
\text { development }\end{array}$ \\
\hline \multirow{2}{*}{$\begin{array}{l}\text { Innovation } \\
\text { as a result }\end{array}$} & $\begin{array}{l}\text { Innovative } \\
\text { product }\end{array}$ & $\begin{array}{l}\text { Intangible assets, property, } \\
\text { plant and equipment, } \\
\text { innovative technologies and } \\
\text { developments }\end{array}$ & $\begin{array}{l}\text { Brand, consumer capital, } \\
\text { environmental capital, intellectual } \\
\text { capital, organizational capital }\end{array}$ \\
\hline & $\begin{array}{l}\text { Innovative } \\
\text { production }\end{array}$ & $\begin{array}{l}\text { The cost of manufacturing } \\
\text { innovative products, goods, } \\
\text { works, services }\end{array}$ & $\begin{array}{l}\text { Client capital, brand, image, } \\
\text { consumer commitment }\end{array}$ \\
\hline $\begin{array}{l}\text { Expected } \\
\text { results from } \\
\text { innovations }\end{array}$ & $\begin{array}{l}\text { Income, } \\
\text { costs, risks, } \\
\text { profitability, } \\
\text { expected } \\
\text { cash flows }\end{array}$ & - & $\begin{array}{l}\text { The factor of the predominance of } \\
\text { the market value of the company } \\
\text { over its value in the accounting } \\
\text { system (the amount specified in the } \\
\text { statement of financial position), } \\
\text { internal goodwill }\end{array}$ \\
\hline
\end{tabular}

Source: author's development 
To build a form of integrated reporting on innovations in the management of the company's value, the indicators must be distributed by type of innovation and the order of reflection in the system of financial accounting and reporting. Innovation as a process details information about the innovative activity of the enterprise through the accounting data on capital investments, innovation costs (period costs), training costs and staff training. Innovations as a result are separately reflected in the composition of the innovative product and innovative products. For each type of innovation there is a corresponding article that affects the value of the enterprise, reflected in the financial statements and off-balance sheet off-balance sheet indicators of generating the company's value.

Integrated reporting on innovations in company value management contains an important indicator of the expected results from innovations, which are determined in the projected amounts of income, expenses, risks, profitability and cash flows from innovation activities and the implementation of innovations in the market. Due to the forecast nature, they will be detailed in the off-balance sheet group of factors shaping the value of the company, which is most consistent with the profitable promising approach to business valuation.

The procedure for submitting statistical information on innovation in the European Union is carried out in accordance with the guidelines of the CIS (Community Innovation Survey) [17]. In order to compile statistical reporting, the information in the account is distributed between innovation processes and innovative products. Information on organizational and marketing innovations is provided separately. It provides important information on innovation expenditures, sources of information, innovation goals and cooperation with other enterprises and organizations in the context of innovation. Enterprises should identify factors that hinder innovation, provide information on the use of methods to stimulate new ideas and creative approaches among employees.

\section{Conclusion}

Innovation is considered as an innovation in the use of a new or qualitatively improved product, product, service or process, organizational or marketing method, organization of jobs or external relations in the activities of the enterprise. A sign of innovation is the requirement that the product, process, method of marketing or organization for the company was new or significantly improved and implemented, implemented in the market.

As an object of accounting innovation should be considered, on the one hand, as an asset - the result of innovation, which can be reflected in non-current assets and accounted for as fixed assets (innovative equipment, machinery, technology) and intangible assets (know-how, patents, licenses for the use of inventions, industrial designs, research and development results). As part of current assets, innovation should be divided into innovative finished products, works and services, the cost of which is reflected in the accounts of production and cost of sales. On the other hand, in the accounting of innovation should be assessed as a process that is accompanied by the cost of innovation in the implementation of scientific advances or capital investment in the creation of innovative objects. The forms of financial statements (statement of financial position, income statement) do not separately display information about the availability of innovative assets or the results of innovative activities of the enterprise, which does not allow to isolate and evaluate such information. Innovation as an object of accounting should be divided into appropriate types, as they require different methods for recognition and reflection and do not equally affect the formation of the company's value.

For the accounting and effective management of innovations it is important to form integrated management reporting as a source of reliable and complete information about the impact of innovation on the growth of the company's value. The need to present data on 
innovation as a process, result and expected benefits in the integrated reporting, as well as according to whether the objects of accounting will be presented in the financial statements or as off-balance sheet indicators and factors generating company value. Innovation as a process details information about the innovative activity of the enterprise through the objects of accounting: capital investment, the cost of innovation as the cost of the period, the cost of training and education. Innovations as a result are reflected in the context of innovative product and innovative products. For each type of innovation, there is a corresponding item that affects the value of the company, reflected in the financial statements, and possible off-balance sheet non-accounting indicators that can affect the market value of the company and related to goodwill. Integrated innovation reporting should include important indicators of expected innovation results, revenues, costs, risks, profitability and cash flows from innovation. They are detailed in the off-balance sheet group of factors and correspond to the income approach to valuation of the enterprise.

The definition of the methodology for evaluating innovations by stages of implementation, identification of the transition of intellectual capital to innovation and feedback is still relevant today. Accounting and reporting should be a tool that helps to implement innovations, their understanding and the most complete information support for making important decisions about the value management of companies.

Accounting for innovations in the value management system of companies today is limited by the current accounting methodology defined in international financial reporting standards. They provide strict criteria for recognizing the assets, costs and results of innovation, but do not fully reflect intangible assets related to innovation, which significantly affect the value formation of companies. This is mainly due to the limitations in the reflection of the intellectual capital of the enterprise in the implementation of innovations, as well as environmental capital, as they are an important reason for the deviation of the market and book value of the enterprise. Therefore, there is a need to consider such objects of accounting in the internal management reporting forms. Prospects for further research are the search for new approaches and improvement of existing methods of reflection in the system of accounting and reporting of enterprise innovations and the impact of their results on the formation of the value of companies, increasing their competitiveness.

\section{References}

1. Schwab, K. (2019). The Global Competitiveness Report 2019. World Economic Forum. Insight Report, Geneva.

2. Kutsyk, P., Koryagin, M., Chik, M., Kuskova S. (2019). Development of evaluation the market value of the enterprise in the system of accounting and analytical support. Independent Journal of Management \& Production, 10(7), 623-644.

3. Simpson, A., Tamayo, A. (2020). Real effects of financial reporting and disclosure on innovation. Accounting and Business Research, 50(5), 401-421.

4. Cooper, S. (2020). Real effects of financial reporting and disclosure on innovation - a practitioner view. Accounting and Business Research, 50(5), 422-424.

5. Semenova, S. (2019). Classification of innovations as an accounting objective. Scientific journal «European Science», 2, 28-38.

6. Sajjad, M., Orangzab, Chani, M. I. (2020). Business Innovations for Unfolding Stratums of Human Development Indicators: a Worldwide Empirical Analysis. Marketing and Management of Innovations, 3, 11-21. 
7. Chaney, P. K., Gunn, R. N., Jeter, C. D. (2020). Implications of Changes in GAAP for Business Combinations (and Goodwill) on Accounting and Finance Research. The International Journal of Accounting, 55(02), Art. No. 2050006.

8. Mazaraki, A. A., Fomina, O. V. (2016). Tools for management accounting. Economic Analis-XXI, 159(5-6), 48-51.

9. Yazdifar, H., Askarany, D., Wickramasinghe, D., Nasseri, A., Alam, A. (2019). The Diffusion of Management Accounting Innovations in Dependent (Subsidiary) Organizations and MNCs. The International Journal of Accounting, 54(01), Art. No. 1950004.

10. Park, K. (2018). Financial reporting quality and corporate innovation. Journal of Business Finance and Accounting, 45(7-8), 871-894.

11. Fomina, O., Moshkovska, O., Luchyk, S., Manachynska, Y., Kuzub, M. (2020). Managing the agricultural enterprises' valuation: Actuarial approach. Problems and Perspectives in Management, 18(1), 289-301.

12. Dainienè, R., Dagilienè, L. (2014). Accounting-based Valuation of Innovation: Challenges and Perspectives. Procedia - Social and Behavioral Sciences, 156(2014), 589-593.

13. Kovova, I., Malyshkin, O., Vicen, V., Shulyarenko, S., Semenova, S., Shpyrko, O. (2018). Value added tax: effectiveness and legal regulation in Ukraine and the European Union. Economic Annals-XXI, 171(5-6), 4-14.

14. Becker, S. D., Messner, M., Schäffer, U. (2020). The Interplay of Core and Peripheral Actors in the Trajectory of an Accounting Innovation: Insights from Beyond Budgeting. Contemporary Accounting Research, Early Access: September 2020.

15. International Financial Reporting Standards (IFRS). International Federation of Accountants. Retrieved from : https://www.ifac.org.

16. Zakon Ukrainy "Pro innovaciynu diyalnist". (n.d.) zakon2.rada.gov.ua. Retrieved from http://zakon3.rada.gov.ua/laws/show/40-15

17. The Community Innovation Survey (CIS). (2014). Methodological recommendations. Retrieved from: https:/epp.eurostat.ec.europa.eu/cache/ITY_SDDS/en/ inn_esms.htm\#stat_pres 